\title{
Effect of Drying Methods on Some Chemical Characteristics of Hazelnuts (Corylus avellana L.) During Storage*
}

\author{
Ali TURAN ${ }^{1}$, Ali İSLAM ${ }^{2}$
}

\begin{abstract}
This study was conducted to determine the effects of different drying methods of sun-dried (grass and concrete ground) machine drying on chemical properties of Levant quality hazelnut in coastal region (Ordu, Turkey) during storage. In conventional drying, only solar energy was used and the drying time was about 50-58 h (concrete ground and grass ground, respectively), and in the drying machine it lasted about $30 \mathrm{~h}$. After the drying and storage time, while the highest rancimat value $(5.73 \mathrm{~h})$ and the lowest peroxide value $\left(0.27 \mathrm{meqO}_{2} \mathrm{~kg}^{-1}\right)$ were found in the drying machine and the concrete ground gave the lowest free fatty acid $(0.04 \%)$. At the end of the storage period, the lowest free fatty acid and peroxide value were determined on concrete ground $(0.29 \%)$ and on drying machine $\left(0.00\right.$ meqO $\left.\mathrm{kg}^{-1}\right)$, respectively. In addition, total aflatoksin and aflatoxin $\mathrm{B}_{1}$ were not detected in any drying methods during storage. As a result, the drying machine was more effective than the other two drying methods for nut quality and preservation. In addition, it has been observed that hazelnuts can be stored for 24 months without significant change in nut quality in room conditions.
\end{abstract}

Keywords: Drying machine, free fatty acid, rancimat value, storage, sun-dried.

\section{Findıkta (Corylus avellana L.) Kurutma Yöntemlerinin Muhafaza Süresince Bazı Kimyasal Özellikler Üzerine Etkisi}

\begin{abstract}
ÖZET: Bu çalışma, sahil kuşak (Ordu, Türkiye) Levant kalite findıklarda makineli kurutma ve geleneksel kurutma yöntemlerinin (güneşte kurutma; beton harman ve çimen harman) depolama boyunca meyvelerin kimyasal özellikleri üzerine etkilerini belirlemek amaciyla yürütülmüştür. Geleneksel kurutma işlemlerinde sadece güneş enerjisi kullanılmış ve kuruma yaklaşık 50-58 sa (beton harman ve çimen harman, sırasılla), kurutma makinesinde ise yaklaşık 30 sa sürmüştür. Kurutma süreci sonrasında en yüksek ransimat değeri (5.73 sa) ve en düşük peroksit değeri $\left(0.27 \mathrm{meqO}_{2} \mathrm{~kg}^{-1}\right)$ kurutma makinesi ortamında, en düşük serbest yağ asitliği değeri ise beton harmanda (\% 0.04) tespit edilmiştir. Muhafaza süresi sonunda ise en düşük serbest yağ asitliği değeri beton harmanda (\% 0.29), en düşük peroksit değeri kurutma makinesi ortamında $\left(0.00 \mathrm{meqO}_{2} \mathrm{~kg}^{-1}\right)$ kaydedilmiştir. Ayrıca depolama süresince hiçbir uygulamada aflatoksin $B_{1}$ ve toplam aflatoksin tespit edilmemiştir. Çalışma sonucunda, kurutma makinesi meyve kalitesi ve muhafazası üzerine diğer iki ortama göre daha etkili olmuştur. Ayrıca çalışma sonucunda, fındıkların adi depo şartlarında kalite özelliklerinde önemli bir değişiklik olmadan 24 ay süreyle muhafaza edilebileceği görülmüş̧ür.
\end{abstract}

Anahtar Kelimeler: Kurutma makinesi, serbest yağ asitliği, ransimat değeri, depolama, güneşte kurutma.

\footnotetext{
Ali TURAN (0000-0002-2961-6605), Giresun University, Teknik Bilimler Meslek Yüksekokulu, Fındık Eksperliği Programı, Giresun, Türkiye

Ali İSLAM (0000-0002-2165-7111), Ordu Universitesi, Ziraat Fakültesi, Bahçe Bitkileri, Ordu, Türkiye Sorumlu yazar/Corresponding Author: Ali TURAN, alituran61@gmail.com

Bu çalışma 4-7 Ekim 2016 tarihinde düzenlenen VII. Bahçe Ürünlerinde Muhafaza ve Pazarlama Sempozyumu'nda sunulmuştur.
} 


\section{INTRODUCTION}

Hazelnuts grown in Turkey are found between $37-42^{\circ}$ latitude and $40-41^{\circ}$ longitude within these boundaries, the most suitable areas in terms of ecological conditions are the Black Sea shores. Hazelnut cultivation reaches up to $60 \mathrm{~km}$ inland and $750 \mathrm{~m}$ in height from the Black Sea coast (Köksal, 2002). In these areas, it is divided into three sections according to the distance from the coast and its height. The areas $0-250 \mathrm{~m}$ above sea level and $10 \mathrm{~km}$ inner area are coastal section, 251-500 m height and 10-20 km inside area, middle section and 501-750 $\mathrm{m}$ height and more than $20 \mathrm{~km}$ inner area is called the high section (Turan, 2017). According to hazelnut quality specifications, Giresun and Levant quality are divided into two. Tombul hazelnuts produced in this region, including Vakfikebir district of Trabzon province, from Piraziz district east of Ordu province are named as Giresun quality. Hazelnuts produced in regions outside Giresun region are called Levant quality hazelnuts (Fiskobirlik, 2004). It is named for the region where it is produced in trade (Akçakoca, Ordu and Trabzon) and is of lower quality than Giresun quality. Although the Black Sea Region has the most qualified hazelnut varieties and ecology of the world, modern hazelnut management is not common. The inability to use modern techniques in cultural practices reduces the quality of the nut on one side and increases the postharvest losses on the other. Especially, mistakes made during the drying stage lead to significant quality losses in hazelnut, leading to major problems in product preservation and marketing stages (Turan, 2017). Thus, rapid postharvest processing of hazelnut, particularly drying, is crucial for the quality of the last product during storage. Because hazelnuts are dried late, there is a risk of mold development and damage by harmful substances (Ozdemir et al., 1998). Hazelnuts should be dried as soon as possible to prevent these risks. Dry and sunny days are needed to dry the nuts by traditional methods. However, during the harvest season, there are few sunny days continuing one after the other due to the ecology of the region, and therefore there is no continuous hazelnut drying opportunity in some periods. In Turkey, only a few study is currently available in the literature the effects of drying methods of sun-dried on grass and concrete ground and machine drying on chemical properties of hazelnut during long-term storage.
Therefore, the aim of this study was to determine the effects of the drying methods of sun drying on grass and concrete grounds, and drying machine on chemical properties of kernels during 24 months of storage.

\section{MATERIALS AND METHODS}

\section{Samples and drying methods}

The experiments were carried out on Levant quality hazelnuts harvested in a single orchard, located in Karapinar neighborhood (latitude $40^{\circ} 57^{\prime} 15.84 \mathrm{~N}$, longitude $37^{\circ} 55^{\prime} 17.32 \mathrm{E}$, altitude $80 \mathrm{~m}$, Altınordu district, Ordu, Turkey). Levant quality hazelnuts consisted of $43.08 \%$ Tombul, $36.56 \%$ Kalinkara and 20.36 $\%$ Palaz cultivars. Nuts in the husks were harvested by hand by picking from the ground after shaking the branches when husks turned into yellow, $3 / 4$ of nut shell browned and husks started to fall. Average kernel moisture was about $25 \%$ at harvest. Husks were laid on grass ground and dehydrated for four days to lose moisture. Then nuts were separated from the husks by huskers, and divided into three groups. The first group was dried under the sun on grass ground (GG): grasses were cut by string trimmer, canvas was laid on ground and samples were placed on canvas to dry in the sun with occasional mixing (Total 3.5 labor). Second group was dried on concrete ground (CG): nuts were directly placed on concrete ground and dried in the sun with occasional mixing (Total 2.5 labor). The last group was dried in drying machine (DM): nuts were placed directly into drying machine and dried with hot air at $45^{\circ} \mathrm{C}$ (FACMA ES 3000) (Total $115 \mathrm{~kW}$ electric energy and 261 diesel oil consumption). Shell and kernel moisture content were measured during all drying periods (Table 1). And also, the drying time was given as hours on the same table. At the end of the drying, the samples were stored under ambient temperature in jute bag and analyzed every three months. Every three months, about $10 \mathrm{~kg}$ in shell (about $5 \mathrm{~kg}$ kernels) samples were taken and total of $100 \mathrm{~kg}$ nuts were used throughout the research.

\section{Storage conditions}

Dried hazelnuts were stored in $10 \mathrm{~kg}$ jute bags in store room at $20-25^{\circ} \mathrm{C}$ temperature and $70-90 \%$ humidity. The samples were stored for 24 months and analyses were performed at three months intervals. 
Table 1. Moisture content of hazelnuts during drying methods, and drying time

\begin{tabular}{|c|c|c|c|c|c|c|c|}
\hline \multirow[t]{2}{*}{ Drying methods } & \multicolumn{2}{|c|}{$\begin{array}{l}\text { Initial moisture } \\
\text { content }(\%)\end{array}$} & \multicolumn{2}{|c|}{$\begin{array}{l}\text { Moisture content after } \\
\text { dehydration }(\%)\end{array}$} & \multicolumn{2}{|c|}{$\begin{array}{l}\text { Final moisture (\%) content, } \\
\text { after drying (prestorage) }\end{array}$} & \multirow[t]{2}{*}{ Drying time (h) } \\
\hline & Shell & Kernel & Shell & Kernel & Shell & Kernel & \\
\hline Concrete ground & \multirow{3}{*}{28.45} & \multirow{3}{*}{25.92} & \multirow{3}{*}{21.70} & \multirow{3}{*}{18.58} & 8.70 & 5.42 & 50 \\
\hline Grass ground & & & & & 9.26 & 6.95 & 58 \\
\hline Drying machine & & & & & 9.03 & 5.89 & 30 \\
\hline
\end{tabular}

\section{Extraction of hazelnut oil}

Oil from hazelnut kernels for free fatty acid (FFA), peroxide value (PV), rancimat value (RV) and aflatoxin (AF) assay were extracted by cold extraction. The hazelnut oil was extracted using a cold pressing method using ceselsan's nut oil extraction system (10 t, AISI, Ceselsan, Giresun, Turkey). Samples of $2 \mathrm{~kg}$ kernel (approximately $4 \mathrm{~kg}$ in shell) were randomly selected and compressed. The recovered oil was classified by centrifugation at $4800 \mathrm{rpm}$ for min and the oil was stored at $-18^{\circ} \mathrm{C}$ in freezer until analyses.

\section{Chemical analyses}

Protein content and lipid content were determined using the AOAC Standard Method (Anonymous, 1990a). Samples of $0.5 \mathrm{~g}$ were used to estimate protein content (PC) (Nx6.25) by macro Kjehldahl method. Lipid content (LC) was determined by extracting a known weight of samples $(5 \mathrm{~g})$ with petroleum ether, using soxhlet apparatus (Venkatachalam et al., 2006). Moisture content (MC) was determined according to TS 3075 (TSE, 2001). Water activity $\left(\mathrm{a}_{\mathrm{w}}\right)$ was determined according to Novasina aw Sprint TH 500 water activity analyzers method (Anonymous, 2004). Free fatty acids were determined by using the AOAC Standard Method (Anonymous, 1990a). 2.5-5 g (m) oil was weighted in a glass vial and dissolved in $25-50 \mathrm{~mL}$ mixture of ethanol, diethyl ether $(1 / 1, \mathrm{v} / \mathrm{v})$ and $2-3$ drops of phenolphthalein were titrated with $\mathrm{NaOH}(0.1 \mathrm{~N})(\mathrm{V})$ until the pink color persisting for at least $10 \mathrm{~s}$. The free fatty acids (FFA) were calculated by the formula: FFA $(\%)=$ $(\mathrm{V} / \mathrm{m}) * 28.2$. To determine peroxide value (PV), 2-2.5 $\mathrm{g}$ of oil was weighted in a glass vial and dissolved in $100 \mathrm{~mL}$ acetic acid/isooctane (3/2, v/v) and supplemented with $0.2 \mathrm{~mL}$ potassium iodide (Anonymous, 1990b). Lingered in a dark place for $5 \mathrm{~min}$ and then 50 $\mathrm{mL}$ distillate water was added. After titration, the value acquired was expressed as meqO $\mathrm{kg}^{-1}$. Rancimat value (RV) was determined by using rancimat 743 devices
(Velasco et al., 2004). Total aflatoxin (AF) and aflatoxin $\mathrm{B}_{1}\left(\mathrm{AFB}_{1}\right)$ were determined by using HPLC (TSE, 2010). Total aflatoxin and aflatoxin $B_{1}$ were calculated by Formula: $\mathrm{m}\left(\mathrm{ngg}^{-1}\right)=50 \mathrm{~g} / 250 \mathrm{mLX} 5 \mathrm{~mL} / 2 \mathrm{~mL}$.

\section{Statistical analysis}

The research was carried out with 3 replications in complete randomized block design. Descriptive statistics were made in the SPSS 22.0 package program. Statistical analyzes were performed in the SAS-JAMP 10.0 package program and LSD test was applied for multiple comparisons.

\section{RESULTS AND DISCUSSIONS}

\section{Protein content}

The effect of drying methods on the protein content (PC) was found to be significant $(\mathrm{p}<0.001)$ (Table 2). Among the drying methods, the highest PC was recorded in the DM (14.13\%) and statistically different from the other two drying methods $(\mathrm{p}<0.001)$. Similarly, results were obtained and it was reported that drying methods affected the ratio of chestnut protein (7.32-8.52\%) (Delgado et al., 2017). However, other studies have reported that drying methods do not affect the PC (Gölükcü, 2015; Kermani et al., 2017). During the storage, the PC was increased in all the drying method with fluctuation $(\mathrm{p}<0.001)$ (Table 2). The highest PC in the study was detected at 21 . month $(18.33 \%)$ of the DM while the lowest value was recorded at 3. months (11.42\%) of the CG. In similar studies as in our study, it was reported that PC increased during storage (Delgado et al., 2017). However, Thakur et al. (2014) reported that the $\mathrm{PC}$ of the pine nuts was not affected during storage.

\section{Lipid content}

The effect of drying methods on lipid content (LC) was not found significant $(\mathrm{p}>0.05)$ (Table 2$)$. Turan and Islam (2016) and Kermani et al. (2017) obtained similar 
results and reported that drying methods were not effective on the LC. However, Delgado et al. (2017) reported that drying methods on chestnuts were effective on LC (2.14-3.07\%). There was no statistically significant change in LC after 24 months of storage ( $p>0.05$ ) (Table 2). Thakur et al. (2014) and Bostan et al. (2016) obtained similar results and reported that the $\mathrm{LC}$ remained almost stable throughout the storage period. However, Turan and Islam (2016) and Koc Güler et al. (2017) show that the LC decreases during the storage period, Koyuncu et al. $(2004 ; 2005)$ reported that the LC increased during the storage period. These differences may be due to drying methods, storage conditions, cultural practices and genetic differences.

\section{Moisture content}

The effect of drying methods on moisture content (MC) was statistically significant $(\mathrm{p}<0.001)$. The highest value in the study was recorded in the DM (4.47 $\%)$ and the lowest values were recorded in the CG and GG (4.36\% and $4.33 \%$, respectively). Turan and Islam (2016) reported similarly that the effect of drying methods on MC was important. In addition, it was reported that the highest value in the study was CG $(4.87 \%)$ and the lowest value was GG (4.66\%). In both studies, the lowest values were recorded on GG and the highest values were recorded on different drying methods. These results may be due to the differences in the cultivars of our study, as well as the shell properties of different thickness. In order to maintain the quality of nuts for a long time without deterioration, the internal moisture must never exceed the $5 \%$ threshold limit (Ghirardello et al., 2013). In our study, the MC varied between 5.57$3.21 \%$ throughout the storage period (Table 2). During storage the MC showed a tendency to decrease with fluctuation $(\mathrm{p}<0.001)$. The highest $\mathrm{MC}$ was recorded at 12. months $(5.57 \%)$ in the DM, while the lowest value was recorded at 18 . months $(3.21 \%)$ in the CG. Similar results were obtained in other studies and the moisture value decreased during storage (Koyuncu et al., 2003; Koc Güler et al., 2017). In another study, however, MC increased in hazelnuts maintained at ambient conditions for twelve months (Ghirardello et al., 2013). On the other hand, Thakur et al. (2014) reported that the $\mathrm{MC}$ was not affected during storage period.

\section{Water activity $\left(\mathbf{a}_{w}\right)$}

Water activity is one of the most important factors affecting fat oxidation (Cam et al., 2008). It is gener- ally known that the rate of oil oxidation at $\mathrm{a}_{\mathrm{w}}$ value of 0.3-0.5 is low. There was no effect on $\mathrm{a}_{\mathrm{w}}$ value of drying methods $(\mathrm{p}<0.001)$ (Table 2$)$. At the beginning of the storage period, the lowest value was recorded in the DM (0.60) and the highest value was recorded in the CG (0.63). At the end of the storage, there was no difference (0.69) between drying methods. Turan and Islam (2016) obtained similar results and reported that drying methods did not affect the $\mathrm{a}_{\mathrm{w}}(0.55)$. The $\mathrm{a}_{\mathrm{w}}$ value was reduced $(p<0.001)$ (Table 2$)$, while fluctuation was observed throughout the storage period. The highest values were recorded at 12 . months $(0.72)$, while the lowest values were recorded at 18. months (0.41). Thakur et al. (2014) and Koc Güler et al. (2017) reported that water activity value decreased during storage. In another study, however, $\mathrm{a}_{\mathrm{w}}$ was reported to increase at the end of the 24. months storage period (0.50-0.54) (Demirci Ercoskun, 2009). It has been reported that AF may develop if the $\mathrm{a}_{\mathrm{w}}$ exceeds 0.83 for two days (Ozay et al., 2008). The $\mathrm{a}_{\mathrm{w}}$ in our study has never exceeded 0.72 in any drying methods and storage time. The $\mathrm{a}_{\mathrm{w}}$ during the study was in the range of 0.72-0.39. In another study, $\mathrm{a}_{\mathrm{w}}$ was reported to be 0.34 in case of $5 \%$ of kernel (Ceylan et al., 2005). These results may be due to the differences in the drying methods and shell characteristics as well as the kernel characteristics.

\section{Free fatty acids}

The effect of drying methods on free fatty acids (FFA) was found to be significant $(\mathrm{p}<0.0001)$ (Table 3 ). At the beginning and end of the storage period, the lowest FFA was detected in CG (0.04-0.29 \%, respectively). There was no difference between the beginning and the end of storage (0.07-0.32\% and 0.07-0.33\%, respectively) on GG and DM. Contrary to our findings, Kashani Nejad et al. (2003) reported that different drying methods did not affect the FFA and there was no difference between sun and other artificial drying. However, Fu et al. (2016) and Qu et al. (2016) reported that drying methods were effective on FFA. In addition, FFA was found to be higher in all of these studies in sun drying. Because lipid molecules release FFA that affect the stability of the oil in temperature and light (Fu et al., 2016) and increase fat oxidation. The FFA decreased except for small fluctuations during the storage period $(\mathrm{p}<0.001)$. The highest value at the end of storage time was found at 21 . months $(0.34 \%)$ while the lowest FFA was recorded at the beginning of storage period $(0.04 \%)$ (Table 3$)$. 


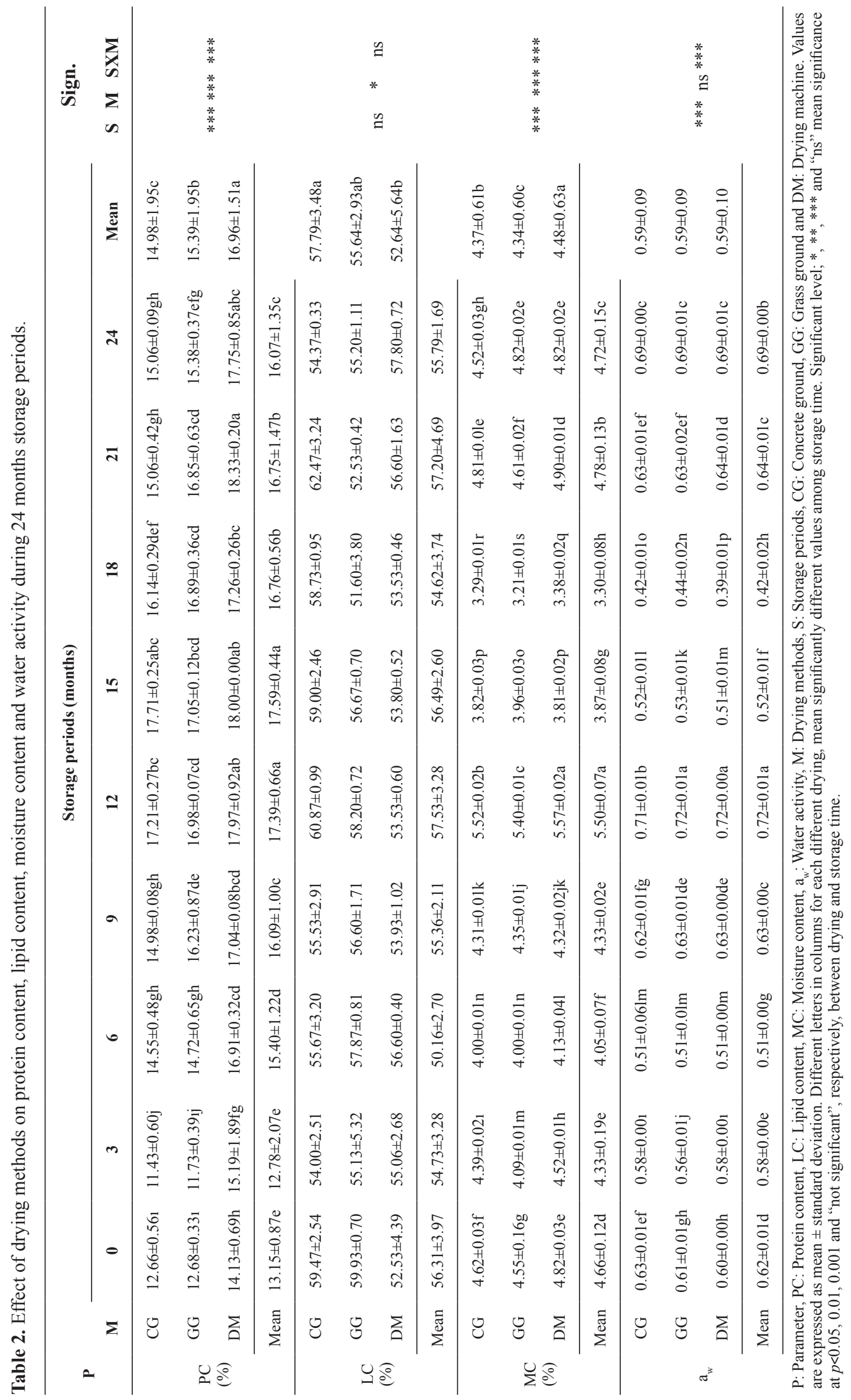




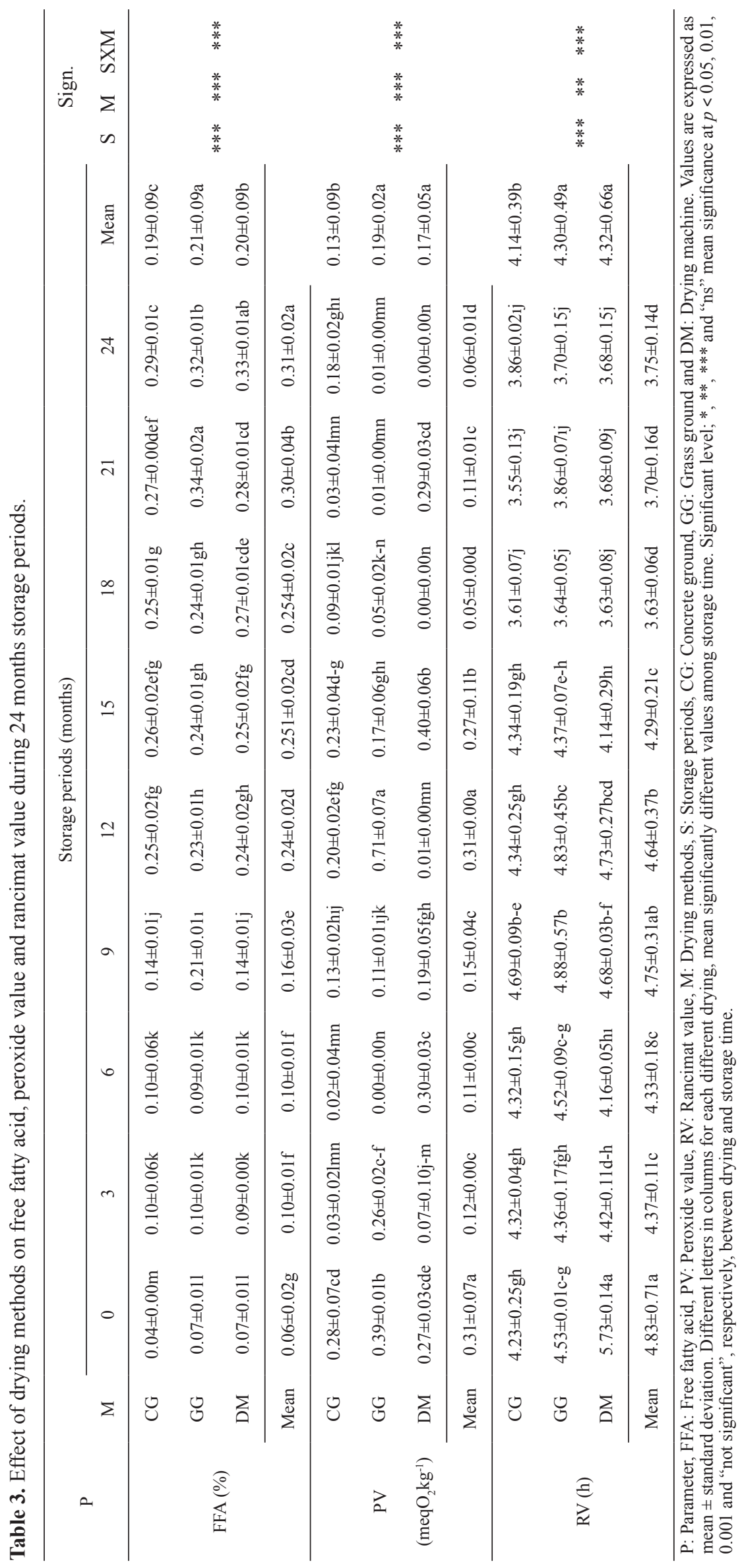


Many studies show that FFA increases during storage (Karaosmanoglu, 2012; Turan and Islam, 2016 and Koc Güler et al., 2017). This increase is variable depending on the temperature and relative humidity of the storage conditions (Tavakolipour et al., 2010). All of the FFA obtained from our study were found to be under $0.4 \%$ (Ghirardello et al., 2013), which is critical acidity for nut industry and $\% 0.7$ (Turan, 2017), which is considered the critical threshold for the hazelnut industry.

\section{Peroxide value}

The effect of drying methods on peroxide value $(\mathrm{PV})$ was found statistically significant $(\mathrm{p}<0.0001)$ (Table 3). The lowest values were found in DM (0.27 meqO $\left.\mathrm{kg}^{-1}\right)$ and the highest values were recorded in GG and CG (0.28-0.39 meqO $\mathrm{kg}^{-1}$, respectively). Similar findings of our study were reported by Fu et al. (2016), Qu et al. (2016) and Kermani et al. (2017) suggested that higher PV were detected in the drying methods of the sun.

The reason is that exposure of hazelnut samples to long-term light and temperature increases fat oxidation. For this reason, it is very important to dry the hazelnut in a short time. But unlike our work, Kashani Nejad et al. (2003) and Turan and Islam (2016) reported higher PV in artificial drying methods. This difference may be due to climate, drying method and genetic factors. In addition to these studies, Koyuncu et al. (2003) reported a lower PV $\left(1.74 \mathrm{meqO}_{2} \mathrm{~kg}^{-1}\right)$ in the study conducted in walnuts compared to drying under sunlight $(0.78$ meqO $\mathrm{kg}^{-1}$ ) in the shade. It is reported that the reason for this is caused by a faster departure from sunny and windy weather than the conditions of the environment where the wind is blowing. During the storage period, the PV increased with fluctuations in some periods $(\mathrm{p}<0.001)$.

Koc Güler et al. (2017) and Turan (2017) reported similarly that the peroxide value increased with fluctuation throughout the storage period. Because during the storage of hazelnut both peroxide formation and peroxide decomposition reactions occur at the same time (Demirci Ercoskun, 2009; Turan, 2017). For this reason, after reaching a peak value of $\mathrm{PV}$, it falls to a value close to zero percent. However, Ghirardello et al. (2013) and Raisi et al. (2015) reported that the PV continuously increased throughout the storage period.

\section{Rancimat value}

Polyunsaturated fatty acids are crucial for oxidative degradation (Moodley et al., 2007), and the high varieties of this feature are generally low in rancimat value (RV). The effect of drying methods on $R V$ was found statistically significant $(\mathrm{p}<0.001)$. The highest value among the drying methods was determined in the DM $(5.73 \mathrm{~h})$ and the lowest value was found in the CG and GG (4.23-4.53 h, respectively). Similar results were obtained from the study conducted by Turan and Islam (2016) and reported higher RV (4.70, 4.32 and $4.33 \mathrm{~h}$, respectively) in the DM than the sun drying (CG and GG). This is because the drying time is shorter in the DM than in the sun drying because the prolongation of the drying time and the increase in temperature increase the oil oxidation. As expected, RV decreased with increasing storage period in all drying methods. $(p<0.001)$ (Table 3). Similarly, it was observed that the value of the rancimat decreased during the storage period (Lopez et al., 1995; Turan, 2017). In present study, the RV in the context of concrete ground, grass ground and drying machine decreased below $4 \mathrm{~h}(3.61,3.64$, $3.63 \mathrm{~h}$, respectively) in 18 . month. The change in the same direction in all drying methods suggests that there may be a threshold time slot value for shelled hazelnut preservation in the 18 . month under ambient conditions.

\section{Aflatoxin}

The GG and CG which are a traditional drying methods, increases the mold growth and mycotoxin risk because they are not hygienic, the drying time changes depending on the climatic conditions and the product is rehydrated. For this reason, DM of hazelnut instead of drying in the sun is suggested as an effective method to prevent AF (Ozay et al., 2008) because, in natural drying conditions, the humidity value can rise very much. Despite the fact that in our work the specimens have been preserved under the common storage conditions which is suitable for the development of fungi, no $\mathrm{AFB}_{1}$ and total $\mathrm{AF}$ have ever been detected in any drying methods and storage time. It has been reported that AF can start at the ripening stage of the nut but not at the level of the formation level, and that the formation concentrates after the harvest (Ozay et al., 2008; Turan, 2007). In addition, it has been reported that Aspergillus flavus is not contaminated with endosperm in firm shell, the product comes into contact with soil in contact with soil, and AF is in the drying stage. 
However, in the study, AF was not detected during the harvest, even though the specimens waited for about a week and were wet.

\section{CONCLUSIONS}

The aim of this study was to determine the effects of the drying methods of sun drying on GG and CG, and DM on chemical properties of hazelnut kernels during 24 months of storage. The FFA increased throughout the storage period and never exceeded $0.34 \%$. The PV increased with the fluctuation during storage and the highest values were recorded in the GG. Furthermore, the lowest $\mathrm{PV}$ at the beginning and end of the storage period was determined in the DM. As expected, the RV was decreased during storage periods. The highest $\mathrm{RV}$ was recorded at the beginning of the storage peri-

\section{REFERENCES}

Anonymous, 1990a. Official Methods and Recommended Practices of the American Oil. Chemist's Society $5^{\text {th }}$ ed., American Oil Chemist Society, USA.

Anonymous, 1990b. Oils and Fats, $15^{\text {th }}$ ed. Official Methods of Analysis of the Association of Official Analytical Chemists, Washington DC, USA, pp: 485-518.

Anonymous, 2004. Operating manual novasina. AW Sprint TH 500 water activity analyzers, Switzerland.

Bostan SZ, Koç Güler S, 2016. Quality changes during in-shell storage of some hazelnut cultivars. Bahçe, 45: 41-53.

Cam S, Kılıc M, 2008. Fındık ürünlerinde acılaşma ve etkili faktörler. GIDA, 33: 97-105.

Ceylan I, Aktas M, Dogan H, 2005. Doğal dolaşımlı, dolaylı ve farklı günes enerjili sistemlerinin deneysel karşılaştırılması. BAÜ Fen Bilimleri Enstitüsü Dergisi, 7: 77-85.

Delgado T, Pereira JA, Ramalhosa E, Casal S, 2017. Comparison of different drying methods on the chemical and sensory properties of chestnut (Castanea sativa M.) slices. Eur. Food Res. Technol. 243: 1957-1971.

Demirci Ercoşkun T, 2009. Research on shelf life of processed hazelnut products. Ankara University Institute of science, (Unpublished) $\mathrm{Ph}$. D. Thesis, 205p.

Fiskobirlik, 2004. Fındık Alım-Ekspertyiz, Saklama, Fındık Kırma, Fındık Kabuğu Satış ve Dağıtımı, Tahvil, Tahliye, Hamaliye, Taşıma, Depo, Fabrika ve Arsa Kiralama Yönetmeliği. Fiskobirlik Basımevi, Giresun.

Fu M, Qu Q, Yang X, Zhang X, 2016. Effect of intermittent oven drying on lipid oxidation, fatty acids composition and antioxidant activities of walnut. Food Sci. Technol-Leb. 65: 11261132. od in the DM (5.73 h). Although the storage condition is compatible with $\mathrm{AF}$ formation and development, $\mathrm{AF}$ has not been detected.

From this, it can be seen that if the AF is not infected and developed during the development of the hazelnut, the storage conditions do not develop even if it is suitable for AF development. As a result of the study, the DM was found more effective on preservation of hazelnut quality than the other two. Moreover, it has been observed that hazelnuts can be stored for 24 months without significant changes in nut quality.

\section{Acknowledgements}

This study was supported by Gürsoy Tarımsal Urünler Gida Sanayi A.S. (Ordu, Turkey). The author wishes to thank Assist. Prof. Fatih ONER for statistical analysis.

Ghirardello D, Contessa C, Valentini N, Zeppa G, Rolle R, Gerbi V, Botta R, 2013. Effect of storage condition on chemical and physical characteristics of hazelnut (Corylus avellana L.). Postharvest Biol. Tec. 81: 37-43.

Gölükcü M, 2015. The effect of drying methods, packaging atmosphere and storage time on dried pomegranate aril quality. J. Agr. Sci. 21: 207-219.

Karaosmanoglu H, 2012. Changes in antioxidant capacity of shelled hazelnuts stored according to conventional methods. 19 May University Institute of science, (Unpublished) Master's Thesis, $77 \mathrm{p}$.

Kashani Nejad M, Tabil LG, Mortazavi A, Safe Kordi A, 2003. Effect of drying methods on quality of pistachio nuts. Dry. Techno. 21: 821-838.

Kermani AM, Khashehchi M, Kouravand S, Sadeghi A, 2017. Effect of intermittent microwave drying on quality characteristics of pistachio nuts. Dry. Techno. 35: 1108-1116.

Koc Güler S, Bostan, SZ, Con AZ, 2017. Effects of gamma irradiation on chemical and sensory characteristics of natural hazelnut kernels. Postharvest Biol. Tec. 123: 12-21.

Koyuncu MA, Koyuncu F, Bakır N, 2003. Selected drying conditions and storage period and nut quality of walnut selections. J. Food Process. Pres. 27: 87-99.

Koyuncu MA, 2004. Change of fat content and fatty acid composition of Turkish hazelnuts (Corylus avellana L.) during storage. J. Food Quality. 27: 304-309.

Koyuncu MA, Islam A, Küçük M, 2005. Fat and fatty acid composition of hazelnut kernels in vacuum packages during storage. Grassy Aceties, 56: 263-266.

Köksal AI, 2002. Turkish Hazelnut Cultivars. Hazelnut Promotion Group, Ankara, Turkey. 136p. 
Lopez A, Pique MT, Romero A, Aleta N, 1995. Influence of cold-storage conditions on the quality of unshelled walnuts. Int. J. Refrig, 18: 544-549.

Moodlay R, Kindness A, Jonnalagadda SB, 2007. Elemental composition and chemical characteristics of five edible nuts (Almond, Brazil nut, Pecan, Macadamia and Walnut) consumed in Southern Africa. J. Environ. Sci. Heal. B. 42: 585-591.

Ozay G, Seyhan Pembeci C, Saklar S, Y1lmaz A, 2008. Factors influencing fungal and aflatoxin levels in Turkish hazelnuts ( $\mathrm{Co}$ rylus avellana L.) during growth, harvest, drying and storage: A 3-year study. Food Addict. Contam. 25: 209-218.

Ozdemir M, Ozay G, Seyhan FG, 1998. Hasattan Ambalaja Findık İşlemenin Kritik Kontrol Noktalarında Tehlike Analizi. Marmara Araştırma Merkezi. Gebze-Kocaeli, Türkiye. 39s.

Raisi M, Ghorbani M, Mahoonak AS, Kashani Nejad M, 2015. Effect of storage atmosphere and temperature on the oxidative stability of almond kernels during long term storage. J. Stored Prod. Res. 62: 16-21.

Tavakolipour H, Armin M, Kalbasi AA, 2010. Storage stability of Kerman pistachio nuts (Pistacia vera L.). Int J Food Eng. 15: $1-11$.

Thakur NS, Sharma S, Gupta R, Gupta A, 2014. Studies on drying and storage of chilgoza (Pinus gerardiana) nuts. J. Food Sci. Technol. 51: 2092-2098.
TSE, 2001. Turkish Standardization Institution, Hazelnut Kernels Standard. TS 3075.

TSE, 2010. Determination of aflatoxins in oil dried fruits. TSE, TS EN ISO 16050.

Turan A, Islam A, 2016. Changes during storage period and the drying methods in the Cakildak hazelnut cultivar. Ordu Univ. J. Sci. Tech. 6: 272-285.

Turan A, 2017. Effect of drying methods on nut quality and storage of hazelnut. Ordu University Institute of science, (Unpublished) Ph. D. Thesis, 231p.

Velasco J, Anderson ML, Skibsted LH, 2004. Evaluation of oxidative stability of vegetable oils by monitoring the tendency to radical formation. A comparison of electron spins resonance spectroscopy with the rancimat method and differential scanning calorimetry. Food Chem. 85: 623-632.

Venkatachalam M, Sathe SK, 2006. Chemical composition of selected edible nut seeds. J. Agr. Food Chem. 54: 4705-4714.

Qu Q, Yang X, Fu M, Chen Q, Zhang X, He Z, Qiao X, 2016. Effects of three conventional drying methods on the lipid oxidation, fatty acids composition, and antioxidant activities of walnut (Juglans regia L.). Dry. Techno. 34: 822-829. 